\title{
ANNOUNCEMENTS
}

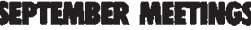

Sept. 7-11. 7th Cold Spring Harbor Meeting on Cancer Cells: The Molecular Diagnostics of Human Cancer. Cold Spring Harbor, NY. Info: Meetings Coordinator, CSHL, Cold Spring Harbor, NY 11724

Sept. 11-16. International Congress by EUCARPIA on Genetic Manipulation in Plant Breeding: Biotechnology for the Breeder. Elsinore, Denmark. Info: Genet ic Manipulation in Plant Breeding, DIS Congress Service, Linde Allé 48, DK-2720 Vanløse, Copenhagen, Denmark

Sept. 14-18. Cold Spring Harbor Meeting on Modern Approaches to New Vaccines Including Prevention of AIDS. Cold Spring Harbor, NY. Info: See for Sept. 711.

Sept. 19-20. Advances in Biotechnology of Membrane Ion Transport. L'Aquila, Italy. Info: Ares-Serono Symposia, Via Ravenna 8, 00161 Rome, Italy

Sept. 19-24. Biotech Expo 88: The 2nd International Exposition and Symposium on Biotechnology and Life Sciences. Shanghai, P.R.C. Info: Grace Chik, China International Convention Service Ltd. Suite 602, Harbour Crystal Centre, TST East, Kowloon, Hong Kong

Sept. 20-22. Biotechnica '88 (4th International Congress and Exhibition for Biotechnology). Hannover, F.R.G. Info: Hannover Fairs USA Inc., 103 Carnegie Center, Princeton, NJ 08540

Sept. 23. From Cell to Field: Current Advances in Plant Biotechnology. Harpenden, Herts., U.K. Info: M. G. K. Jones, Rothamsted Experimental Station, Harpenden, Herts. AL5 2JQ, U.K.

Sept. 25-29. 4th International Congress on Computer Applications in Fermentation Technology: Modelling and Control of Biotechnological Processes. Cambridge, U.K. Info: Conference Dept., Society of Chemical Industry, 14/15 Belgrave Square, London SW1X 0PS, U.K.

Sept. 25-30. American Chemical Society 196th Semi-annual Meeting. Los Angeles, CA. Info: Nancy Enright, ACS, 115516 th St., N.W., Washington, DC 20036

Sept. 26-28. 12th Annual Meeting of the Regulatory Affairs Professionals Society. Alexandria, VA. Info: RAPS Headquarters, 1101 Connecticut Ave. N. W., Washington, DC 20036

Sept. 26-30. 9th Meeting of the European Society for Animal Cell Technology: Advances in Animal Cell Biology and Technology for Bioprocesses. Knokke, Belgium. Info: J. M. Duval, ICC, rue de Roosendael 88 (b 1), B-1190 Brussels, Belgium
Sept. 28-29. Nature's 11th International Conference: How The Brain Works. Cambridge, MA. Info: Diana Berger, Nature Publishing Company, 65 Bleecker St., New York, NY 10012 (Phone 212 . 477-9600)

Sept. 29. Forum for Applied Biotechnology. Ghent, Belgium. Info: Administrative Center FAB, p/a GOM - West-Vlaanderen, Baron Ruzettelaan 33, B-8320 Brugge 4 , Belgium

\section{CCTOBar Mantures}

Oct. 3-5. Advances in Recombinant DNA Technology: Genetic Engineering and the Immune System. Incline Village, NV Info: Symposium Coordinator, The Center for Advanced Training in Cell and Molecular Biology, The Catholic University of America, Washington, DC 20064

Oct. 5-7. The PaineWebber-Bio/Technology Conference: Biopharmaceuticals Futures. San Diego, CA. Info: Diana Berger, Biopharmaceuticals Futures, Nature Publishing Co., 65 Bleecker St., New York, NY 10012-2467 (Phone: 212-477. 9600)

Oct. 11-15. American Society of Human Genetics 1988 Annual Meeting. New Orleans, LA. Info: Peggy Gardiner, Meetings Manager, American Society of Human Genetics, 9650 Rockville Pike, Bethesda, MD 20814

Oct. 24-25. Frontiers of Chemistry: Biotechnology. Columbus, OH. Info: Dr. Stobaugh, Research Dept., Chemical Abstracts Service, P.O. Box 3012, Columbus, $\mathrm{OH} 43210$

Oct. 31-Nov, 2. Growth Factors for Wound Healing. New Haven, CT. Info: Technology Management Group, 25 Science Park, New Haven, CT 06511

\section{WOUTMBER METIUCS}

Nov. 6-9. Biomodulation of Cancer. Berkeley, CA. Info: Society for Biological Therapy 1988, c/o A. S. M. Meetings, 1913 Eye St. N. W., Washington, DC 20006

Nov. 14-16. Biotech USA The 5th Annual Industry Conference and Exhibition. San Francisco, CA. Info: Biotech USA '88, c/o CMC, 200 Connecticut Ave., Norwalk, CT 06856-4990 Tel: 1-800-2433238 ext.232

Nov. 16-19. Biotec ' 88 . Düsseldorf, West Germany. Info: Düsseldorfer Messegesellschaft $\mathrm{mbH}$, NOWEA, Kongreßbüro BIOTECH '88, Postfach 3202 03, D-4000 Düsseldorf 30, West Germany

Nov. 21-22. Recent Progress in Cytokine Research. Tokyo, Japan. Info: Secretariat, Masahiro Nobuhara, Director, Life Science Affairs, Mochida Pharmaceutical Co., Ltd., 1-7, Yotsuya, Shinjuku-ku, Tokyo 160, Japan
Nov. 29-Dec. 1. Equipment Design for Bioprocess Engineering Colloquium. Chicago, IL. Info: Julie Trunzo Lee, The American Society of Mechanical Engineers, 345 East 47 th St., MS/5A, New York, NY 10017

Nov. 29-Dec. 1. BioChemE '88. Washington, DC. Info: American Institute of Chemical Engineers, 345 East 47 th St. New York, NY 10017

\section{counds}

Sept. 7-9. Genetic Engineering for Chemists and Chemical Engineers. Berkeley, CA. Info: Continuing Education in Engineering, UC Berkeley Extension, 2223 Fulton St., Berkeley, CA 94720

Sept. 12-15. Industrial Bioprocessing: Principles and Practice of Bioprocessing Systems. Estes Park, CO. Info: Gwynne Hallock, Office of Conference Services, Rockwell Hall, Colorado State University, Fort Collins, CO 80523

Sept. 19-23. Fungal Biotechnology Course. Loch Lomond, U.K. Info: John E. Smith, Dept. of Bioscience \& Biotechnology, Div. of Applied Microbiology, Univ. of Strathclyde, 204 George St., Glasgow, G1 1XW, U.K.

\section{XXCUIVT CHANes}

Human Genome Center at Lawrence Berkeley Laboratory (Berkeley, CA) named Charles $\mathrm{R}$. Cantor director. He is a professor and chairman of genetics and development at Columbia University.

Edison BioTechnology Center (Cleveland, $\mathrm{OH}$ ) appointed Dorothy C. Baunach president.

Genzyme (Boston, MA) elected Henri A. Termeer chairman.

Gene-Trak Systems (Framingham, MA) the joint venture between Integrated Genetics, Inc. and Amoco Corporation, named Patrick J. Connoy president.

Ministry of International Trade and Industry (Tokyo, Japan) appointed Masaru Masuda director of its Bioindustry Office.

Ares-Serono Group (Boston, MA) named Phillip T. Vogel president and chief operating officer of Serono Diagnostics worldwide.

Smith Kline \& French Laboratories (Philadelphia, PA) appointed George W. Ebright as its president.

Biogen N. V. (Cambridge, MA) announced that Vicki L. Sato will head the research organization and serve on the company's scientific board. The company also named Michael R. Slater vice president of quality assurance and regulatory affairs. 